\title{
Emergency service admissions of patients with burn injury
}

\author{
Yanık hastalarının acil servis başvuruları
}

\author{
Sadiye Yolcu' ${ }^{1}$, Nesrin Gökben Beceren ${ }^{2}$, Hüseyin Timuçin ${ }^{3}$, Ulaş Uludağ ${ }^{4}$
}

\begin{abstract}
Objective: In this study, we aimed to investigate the properties of burn injured patients who admitted to our hospital emergency service.
\end{abstract}

Methods: Patients were detected from the hospital records of emergency service during six months period and were divided into five groups according to their ages $(<10$, $11-20,21-40,41-60$ and $>60$ years). Age, gender total body surface area (TBSA), mechanism of injury and the outcome of emergency evaluation were recorded.

Results: Totally 111619 patients admitted to our emergency service between 01.07.2011 and 31.12.2011. During six months, 2349 males and 1960 females totally 4309 patients were burn injured patients. 1773 patients were between 0-10 years, 1083 patients were 11-20 years, 735 patients were between 21 and 40,361 patients were between 41 and 60 and 357 patients were over 60 years. Most of the patients were treated in the emergency service (90.1\%). 0-10\% TBSA patients constituted $94.2 \%$. This ratio for burn area $>40 \%$ was $0.6 \%$. Hot liquid burn (vapored water, milk etc.) was $60.2 \%$. There was a significant relation between mechanism of burn injury and age groups $(p<0.05)$. No corrosive and sunburn injuries determined in females. Age groups were related with hospitalization $(p<0.05)$. The highest intensive care unit admission was found in the $0-10$ age group (1.3\%).

Conclusion: Emergency service is the first admission department of burn injury patients. Knowing the properties of burn injury patients, would help hard-working emergency doctors in triage of these patients. Also, reporting the data of emergency service burn injury patients would be helpful for further studies. J Clin Exp Invest 2013; 4 (3): 285-288

Key words: Burn injury, emergency service, total body surface area

\section{ÖZET}

Amaç: Bu çalışmada hastanemiz acil servisine başvuran yanıklı hastaların özelliklerini araştırmayı amaçladık.

Yöntemler: Acil servisimize altı aylık sürede başvuran yanık hastaları hastane otomasyon sisteminden belirlendi. Hastalar yaşlarına göre beş gruba ayrıldı $(<10,11-20$, 21-40, 41-60 ve > 60 yaş). Yaş, cinsiyet, TYYA (total yanık yüzey alanı), yanık mekanizması ve acil serviste sonuçlanma şekli kaydedildi.

Bulgular: Hastane verilerine göre 01.07.2011-31.12.2011 tarihleri arasında acil servisimize toplam 111619 hasta başvurmuştu. Altı aylık süre boyunca, 2349 erkek, 1960 kadın toplam 4309 yanık hastası başvurusu tespit edildi. 1773 hasta 0-10 yaş grubunda, 1083 hasta 11-20, 735 hasta 21-40, 361 hasta 41-60 yaş aralığında ve 357 hasta $>60$ yaş idi. Hastaların çoğu acil serviste ayaktan tedavi edilerek taburcu edilmiş idi (\%90,1). TYYA oranı \%0-10 olan hastaların oranı \%94,2 idi. >\%40 yanık alanı olan hasta oranı \%0,6 idi. Sıcak sıvı ile oluşmuş yanık (kaynamış su, süt vs.) oranı \%60,2 idi. Yaş grupları ile yanık mekanizması arasında anlamlı bir ilişki tespit edildi $(p<0,05)$. Yine yaş grupları ve hospitalizasyon arasında anlamlı bir ilişki bulundu $(p<0,05)$. En yüksek yoğun bakıma yatış olan grup 0-1 yaş aralığı idi $(\% 1,3)$.

Sonuç: Acil servis yanık hastalarının ilk başvurdukları bölümdür. Yanıklı hastaların genel özelliklerinin bilinmesi, bu hastaların triajında çok yoğun çalışan acil servis hekimlerine yardımcı olabilecektir. Ayrıca, yanık hastalarının acil servis verilerinin rapor edilmesi ileride yapılacak çalışmalar için aydınlatıcı olacaktır.

Anahtar kelimeler: Yanık yaralanması, acil servis, total yanık yüzey alanı

${ }^{1}$ Bozok Üniversitesi, Tıp Fakültesi, Acil Tıp Servisi, Yozgat, Türkiye

2 Süleyman Demirel Üniversitesi, Tıp Fakültesi, Acil Tıp Anabilim Dalı, Isparta, Türkiye

${ }_{3}^{3}$ Şanlıurfa Eğitim Araştırma Hastanesi, Yanık Ünitesi, Şanlıurfa, Türkiye

${ }^{4}$ Isparta Devlet Hastanesi Ortopedi Kliniği, Isparta, Türkiye

Correspondence: Sadiye Yolcu,

Bozok Üniversitesi, Tıp Fakültesi Acil Tıp Servisi, Yozgat, Türkiye Email: sadiyeyolcu@yahoo.com Received: 04.07.2013, Accepted: 15.07.2013

Copyright (C) JCEI / Journal of Clinical and Experimental Investigations 2013, All rights reserved 


\section{INTRODUCTION}

Burn is defined as tissue injury due to exposure of heat, electric, chemicals/corrosives and radioactive rays. This tissue injury depends on duration of exposure time and the intensity [1]. Most of the people sustain burn injury at least once during lifetime. It is a kind of trauma and may be a simple injury or presents more complicated that threats life due to infection, shock and multi-organ failure. Burns constitute a major health problem because of morbidity and mortality [2]. Thermal burns and related injuries are major causes of death and disability in young population.

Easy encounter, affecting all age groups and precautional deficiencies trigger an important part of emergency service admissions [3].

In the emergency room burn injury management should be similar to trauma patients $[4,5]$. Knowing the intensity and extent of burn help both appropriate triage and treatment. Depth of burn injury is expressed with grade, extent is expressed with percentage of burned area to total body area. This percentage is simply calculated with nines rule [6].

In the present study we investigated the properties of burn injury patients admitted to our emergency service.

\section{METHODS}

In this retrospective study burn injured patients were determined who admitted to Hospital Emergency service between 01.07.2011-31.12.2011. Patients were divided into five groups according to their ages $(<10,11-20,21-40,41-60$ and $>60$ years). Age, gender, total body surface area (TBSA), mechanism of injury and the outcome of emergency evaluation of the patient groups were recorded. All burn injury patients admitted to our emergency service were included to our study.

The normal distribution and homogeneity of each parameter was tested by Kolmogorov Smirnov test. Data of the patient group was not suitable for normal distribution. Non parametric test Chi-Square test was used. Spearman's correlation coefficient is used for binary correlations. In all test significance level $p<0.05$. SPSS (Statistical Package for the Social Sciences) software 20.0 was used for all analysis.

\section{RESULTS}

According to hospital data, totally 111619 patients admitted to our emergency service between 01.07.2011-31.12.2011. During six months, 2349 males and 1960 females totally 4309 patients were burn injured patients. 1773 patients were between 0-10 years, 1083 patients were 11-20 years, 735 patients were between 21 and 40 years, 361 patients were between 41-60 years and 357 patients were over 60 years. Most of the patients were treated in the emergency service (90.1\%). 0-10\% TBSA patients' ratio was $94.2 \%$. This ratio for burn area $>40 \%$ was $0.6 \%$. Hot liquid burn (vapored water, milk etc) burn ratio was 60.2 followed by flare burn with a percentage of $18.5 \%$. Patients' detailed data is given in table 1 .

Table 1. Distribution of burn injuries according to mechanism, age and total body surface area

\begin{tabular}{|c|c|c|c|c|c|c|c|c|c|c|c|c|c|c|c|c|c|}
\hline & & \multicolumn{4}{|c|}{ Burn Unit } & \multicolumn{4}{|c|}{ Burn ICU } & \multicolumn{4}{|c|}{ Discharged } & \multicolumn{4}{|c|}{ Referred } \\
\hline & & \multicolumn{2}{|c|}{$M$} & \multicolumn{2}{|c|}{$\mathrm{F}$} & \multicolumn{2}{|c|}{$\mathrm{M}$} & \multicolumn{2}{|c|}{$F$} & \multicolumn{2}{|c|}{$M$} & \multicolumn{2}{|c|}{$\mathrm{F}$} & \multicolumn{2}{|c|}{$\mathrm{M}$} & \multicolumn{2}{|c|}{$F$} \\
\hline & & $\mathrm{n}$ & $\%$ & $\mathrm{n}$ & $\%$ & $\mathrm{n}$ & $\%$ & $\mathrm{n}$ & $\%$ & $\mathrm{n}$ & $\%$ & $\mathrm{n}$ & $\%$ & $\mathrm{n}$ & $\%$ & $\mathrm{n}$ & $\%$ \\
\hline \multirow{5}{*}{ Mechanism } & Liquid & 145 & 51.1 & 139 & 48,9 & 4 & 23.5 & 13 & 76,5 & 1235 & 53.9 & 1058 & 46.1 & 0 & 0 & 0 & 0 \\
\hline & Fire & 45 & 50.6 & 44 & 49.4 & 4 & 100 & 0 & 0 & 530 & 75.1 & 176 & 24.9 & 0 & 0 & 0 & 0 \\
\hline & Electric & 14 & 100 & 0 & 0 & 6 & 100 & 0 & 0 & 0 & 0 & 530 & 100 & 3 & 100 & 0 & 0 \\
\hline & Corrosive & 4 & 100 & 0 & 0 & 5 & 100 & 0 & 0 & 176 & 100 & 0 & 0 & 0 & 0 & 0 & 0 \\
\hline & Sun & 1 & 100 & 0 & 0 & 0 & 0 & 0 & 0 & 177 & 100 & 0 & 0 & 0 & 0 & 0 & 0 \\
\hline \multirow{5}{*}{ Age, years } & $0-10$ & 173 & 51.2 & 165 & 48.8 & 11 & 47.8 & 12 & 52.2 & 706 & 50 & 706 & 50 & 0 & 0 & 0 & 0 \\
\hline & $11-20$ & 12 & 63.2 & 7 & 36.8 & 3 & 100 & 0 & 0 & 706 & 66.7 & 353 & 33.3 & 2 & 100 & 0 & 0 \\
\hline & $21-40$ & 18 & 75 & 6 & 25 & 3 & 75 & 1 & 25 & 353 & 50 & 353 & 50 & 1 & 100 & 0 & 0 \\
\hline & $41-60$ & 5 & 83.3 & 1 & 16.7 & 2 & 100 & 0 & 0 & 353 & 100 & 0 & 0 & 0 & 0 & 0 & 0 \\
\hline & $>60$ & 1 & 20 & 4 & 80 & 0 & 0 & 0 & 0 & 0 & 0 & 352 & 100 & 0 & 0 & 0 & 0 \\
\hline \multirow{5}{*}{ TBSA (\%) } & $0-10$ & 102 & 58.3 & 73 & 41.7 & 3 & 100 & 0 & 0 & 2118 & 54.6 & 1764 & 45.4 & 0 & 0 & 0 & 0 \\
\hline & $10-20$ & 71 & 56.3 & 55 & 43.7 & 3 & 75 & 1 & 25 & 0 & 0 & 0 & 0 & 0 & 0 & 0 & 0 \\
\hline & $20-30$ & 28 & 36.4 & 49 & 63.6 & 4 & 100 & 0 & 0 & 0 & 0 & 0 & 0 & 0 & 0 & 0 & 0 \\
\hline & $30-40$ & 2 & 28.6 & 5 & 71.4 & 5 & 100 & 0 & 0 & 0 & 0 & 0 & 0 & 0 & 0 & 0 & 0 \\
\hline & $>40$ & 6 & 85.7 & 1 & 14.3 & 4 & 25 & 12 & 75 & 0 & 0 & 0 & 0 & 3 & 100 & 0 & 0 \\
\hline
\end{tabular}

M: Male, F: Female, ICU: Intensive care unit, TBSA: total body surface area 
There was a significant relation between mechanism of burn injury with age groups $(p<0.05)$. Hot liquid burns was the most common mechanism for all age groups except 41-60 group. In this group ratios were equal for liquid and sun burns. Gender and burn mechanism were related $(p<0.05)$. No corrosive and sun burn injuries determined in females.

Age groups were related with hospitalization $(p<0.05)$. The highest burn ICU (intensive care unit) hospitalization ratio was determined in the $0-10$ age group (1.3\%). Gender was not related with hospitalization $(p>0.05)$ and TBSA ( $p>0.05)$.

Age groups were significantly related with TBSA $(P<0.05)$. Hospitalization and TBSA are significantly related $(p<0.05)$. Burn mechanism and TBSA were fount to be related $(p<0.05)$.

Age groups and mechanism of burn are positive correlated $(p<0.05, r=0.091)$. Age group and hospitalization were positively correlated $(p<0.05$, $r=0,264)$. Age group and TBSA are positively correlated $(p<0.05, r=-0,185)$. Gender is not correlated with hospitalization $(p=0,642 r=-0,007)$, TBSA $(p=0,185 r=0,020)$ and mechanism $(p=0,162 \quad r=-$ $0.021)$

\section{DISCUSSION}

In our study, similar to literature, males were sustained burn injury much more than the females [3]. But some studies report a controversy about gender of burn injuries [7-9]. Most of our patients were under the age of 10 . Discharge ratio from our emergency department was $90.1 \%$. $94.2 \%$ of the patients' TBSA ratio was under $10 \%$. The most common reason for burn injury was hot liquid contact. No corrosive and sun burn injuries determined in females. Al et al reported that $23.1 \%$ of their burn injury patients had been caused by hot liquid in our study this ratio was $60.2 \%$. [10].

In Wu-Chien's study hot liquid burn injury ratio was $88.4 \%$ in childhood burns [11]. But some studies reported higher rates of hot liquid burns in elderly age [12].

Some risk factors have been found to be related with probability of death after burn injuries; these are age $>60$ years, TBSA more than $40 \%$, and the presence of inhalation injury and also burn depth [13].

In our study the highest ICU hospitalization ratio was determined in the $0-10$ age group. Age groups were significantly related with TBSA. Hospitalization and TBSA are significantly related. Burn mechanism and TBSA were fount to be related. Al- though there are statements on the young age as risk factors of burn-related mortality [13], Sheridan and Lundgren reported that age does not interfere with mortality in children [14,15].

The controversy indeed stands as a result of the differences in treatment options, type, severity, and extent of burns in the studied groups of pediatric patients. However, mortality due to burn injuries has been shown to be lower in children and it has been stated that pediatric cases survive even severe incidents of burn $[13,16]$.

Mortality rate of pediatric burns was $10.6 \%$ in Karimi's study [17]. Other studies have also proposed predicting models for burn mortality $[13,16,18]$.

Çoban et al reported 411 burn unit hospitalized patients during 18 months. In our study, number of burn injury patients hospitalized during six month was 4309 . In their study, mortality ratio was $5.6 \%$ [19].

In conclusion, burn injury is a public health problem. These patients first admit to emergency departments. This study would lead emergency physicians to record and report their own emergency services' data of burn injury patients for appropriate triage and initial evaluation of these patients.

\section{REFERENCES}

1. Endorf FW, Ahrenholz D. Burn management. Curr Opin Crit Care 2011;17: 601-605.

2. Brusselaers N, Monstrey S, Vogelaers D, Hoste E, Blot S. Severe burn injury in Europe: a systematic review of the incidence, etiology, morbidity, and mortality. Crit Care 2010;14:188-192.

3. Bayram Y, Yıldırım AO, Eyi E. Emergency in Burn, Burn in Emergency. TAF Prev Med Bull 2012;11:365-368.

4. Moss LS. Treatment of the burn patient in primary care. Adv Skin Wound Care. 2010;23:517-524.

5. Muehlberger T, Ottomann C, Toman N, et al. Emergency pre-hospital care of burn patients. Surgeon 2010;8:101-104.

6. Chen CC, Chen LC, Wen BS, et al. Objective estimates of the probability of death in acute burn injury: A proposed Taiwan burn score. J Trauma Acute Care Surg 2012;73:1583-1589.

7. Mzezewa S, Jonsson K, Aberg M, Salemark L. A prospective study on the epidemiology of burns in patients admitted to the Harare burn units. Burns 1999;25:325-329.

8. Morales EF, Alcaraz LG, Navajas JFC, Garcia EG. Epidemiology of burns in Malaga, Spain. Burns 1997;23:323-332. 
9. Liu EH, Khatri B, Shakya EM, Richard BM. A 3 year prospective audit of burns patients treated at the Western Regional Hospital of Nepal. Burns 1998;24:129-133.

10. Al B, Güllü MN, Okur H, Öztürk H, Kara IH. Doğu Anadolu ve Güneydoğu Anadolu bölgelerinde haşlanma ve alev yanıklarının epidemiyolojik özellikleri. Tıp Araştırmaları Dergisi 2005;3:14-21.

11. Chien W, Pai L, Chan HC. Epidemiology of hospitalized burns in Taiwan. Burns 2003;29:582-588.

12. Lewandowsky R, Pegg SP, Fortier K, Skimming A. Burn injuries in the elderly. Burns 1993;19:513-515.

13. Thombs BD, Singh VA, Milner SM. Children under 4 years are at greater risk of mortality following acute burn injury: evidence from a national sample of 12,902 pediatric admissions. Shock 2006;26:348-352.

14. Sheridan R, Weber J, Schnitzer J, et al. Young age is not a predictor of mortality in burns. Pediatr Crit Care Med 2001;2:223-224.
15. Lundgren RS, Kramer CB, Rivara FP, et al. Influence of comorbidities and age on outcome following burn injury in older adults. J Burn Care Res 2009;30:307314.

16. Muller M, Pegg S, Rule M. Determinants of death following burn injury. Br J Surg 2001;88:583-587.

17. Karimi H, Motevalian SA, Rabbani A, et al. Prediction of mortality in pediatric burn injuries: R-Baux score to be applied in children (Pediatrics-Baux Score). Iran J Pediatr 2013;23:165-170.

18. Osler T, Glance LG, Hosmer DW. Simplified estimates of the probability of death after burn injuries: extending and updating the Baux score. J Trauma 2010;68:690-697.

19. Çoban YK, Erkılıç A, Analay H. Our 18-month experience at a new burn center in Gaziantep, Turkey. Turk J Trauma \& Emergency Surg 2010;16:353-356. 